\title{
Influence of a Native Strain of Staphylococcus xylosus on the Microbiological, Physicochemical and Sensorial Characteristics on Milano Salami Type
}

\author{
Ângela Maria Fiorentini ${ }^{1,2 *}$, Maristela Cortez Sawitzki ${ }^{1}$, Teresinha Marisa Bertol ${ }^{3}$, Anildo \\ Cunha Júnior $^{3}$ and Ernani Sebastião Sant'Anna ${ }^{1}$ \\ ${ }^{I}$ Departamento de Ciência e Tecnologia de Alimentos; Centro de Ciências Agrárias; Universidade Federal de Santa \\ Catarina; Rod. Admar Gonzaga, 1346; 880034-001; Florianópolis - SC - Brasil. ${ }^{2}$ Departamento de Biologia e \\ Química; Universidade Regional UNIJUÍ; RS 344, km 39; 98900-000; Santa Rosa - RS - Brasil. ${ }^{3}$ Embrapa Suínos e \\ Aves; BR 153; km 110; 89700-000; Concórdia - SC - Brasil
}

\begin{abstract}
In this work, the influence of native starter cultures on the microbiological, physicochemical and sensorial characteristics of Milano salami type was studied. Two batches of Milano salami type were produced: Batch A, with the addition of Staphylococcus xylosus U5 and Batch B (control) without the starter culture. The Milano salami type was characterized by an important microbial activity of coagulase-negative staphylococci (CNS) that resulted in substantial growth in Batch A during the ripening with an initial count of 7.60 log $c f u . g^{-1}$ and reached 9.84 log CFU. $g^{-1}$ after 14 days. Bacterial enzymes that showed efficient activity under the conditions found in Milano salami type were catalase, nitrite and nitrate reductase, contributing for sensory and physicochemical properties of the product. There were no significant differences in general free fatty acids composition among the batches, while the color parameters ( $L *, a *$ and $b *$ ) in the Batch A presented significantly higher values in relation to Batch B. Moreover, batch A had the higher preference in sensorial analysis.
\end{abstract}

Key words: Staphylococcus xylosus, starter cultures, milano salami type

\section{INTRODUCTION}

Fermented sausages can be defined as the meat products consisting of a mixture of meat and fat particles, salt, curing agents, spices, etc., which acquire their characteristic properties through a process involving the microorganisms (Hammes, 1990). Spontaneous fermentation has been applied for thousands of years mainly as a method for the preservation of foodstuffs and as a way to obtain the spicy and flavorful foods (Drosinos et al.,
2007). Generally, lactic acid bacteria (LAB) and Micrococcaceae are the main groups involved in the fermentation of dry cured sausages (Lücke and Hechelmann, 1987; Coventry and Hickey, 1991). The manufacturing of fermented sausage has a long history in Brazil. As influence of Italian immigration in the beginning of the $20^{\text {th }}$ century, it is still regarded as the Italian traditions. Even when the use of starter culture has become common in the products, many typical artisanal sausages are still produced with the traditional

*Author for correspondence: afiore@unijui.edu.br 
technologies without selected starters.

A wide variety of microorganisms have already been isolated by traditional methods, from spontaneous fermentations, mainly represented by the coagulase-negative staphylococci (CNS), such as Staphylococcus xylosus, $S$. saprophyticus and $S$. carnosus (Coppola et al., 1997; Garcia-Varona et al., 2000; Papamanoli et al., 2002; Mauriello et al., 2004; Drosinos et al., 2005). Several strains have been isolated and characterized in terms of their technological properties, mainly proteolysis (Fadda et al., 1998; Bover-Cid et al., 1999), lipolysis (Molly et al., 1996; Mauriello et al. 2004), production of antimicrobial compounds (Aymerich et al., 2000; Messens et al., 2003, Drosinos et al., 2007), decarboxylation of specific amino acids (Martuscelli et al. 2000; Bover-Cid et al., 2001) and others (Mauriello et al., 2004).

Coagulase-negative staphylococci (CNS) are important microorganisms in meat products. They have several technological advantages, such as nitrite and nitrate reductase activity, oxygen consumption and catalase activity that improve the colour stability and decrease rancidity development in the product (Geisen, Lücke, and Kröckel, 1992). Berdagué et al., (1993) established a correlation between the type of starter culture and flavour of fermented sausages. Montel et al., (1996) proved that staphylococci contributed to the generation of typical fermented sausage flavor, possibly due to proteolytic and lipolytic capability (Rodríguez et al., 1998; Berdagué et al., 1993).

S. xylosus is one of the main staphylococci species found in most naturally fermented sausages (Montel et al. 1992; Coppola et al. 1997; Rebecchi et al. 1998; Cocolin et al., 2001). Fiorentini et al., (2009) reported its presence in artisanal sausages in South region of Brazil. Due to these properties, S. xylosus is considered as a suitable starter culture in sausage production. In selecting a suitable starter strain, it should be taken into account that the strain must compete with the same species, or with closely-related species, occurring in a single environment, the so-called 'house flora' (Santos et al., 1998). In production of traditional fermented sausages it is important to use selected starter cultures due to a low variability of present microflora. Selected starter cultures consist of isolated strains from local products being well adapted to the particular product and to the specific production technology (Papa and Grazia, 1990). Besides, they could dominate the microflora of fermented meat product (Papamanoli et al., 2003). The Brazilian legislation allows the use of starter cultures and considers them as technological coadjutants (BRASIL, 2000).

A strain of $S$. xylosus U5 was isolated and identified by Fiorentini et al., (2009). This strain was isolated from the indigenous flora of naturally fermented sausages and recommended, due to technological potential, for using as starter cultures in fermented sausage. Therefore, the aim of the present work was to investigate the influence of native starter cultures - Staphylococcus xylosus U5 - on microbiological, physicochemical and sensorial characteristics in Milano salami type.

\section{MATERIALS AND METHODS}

\section{Microorganism}

Staphylococcus xylosus strain U5 is part of a group of microorganisms isolated from artisanal sausages collected in twenty-one cities of South Region of Brazil. The strain S. xylosus U5 was selected as a starter culture on the basis of its catalase positive activity, capacity to reduce nitrate and nitrites, lipolytic activity and no enterotoxin production in broth. It was also subjected to phenotypic and molecular characterization (Fiorentini, et al., 2009).

\section{Starter preparation}

Freeze-dried cultures of $S$. xylosus U5 were resuspended in sterile distilled water in the absence of chlorine and then added to the meat mixture in concentration of $9 \mathrm{log}$ cfu per gram of raw material.

\section{Milano salami type preparation}

Milano salami was manufactured in local industry plants using traditional techniques, selected raw materials and good manufacturing practices. Sausages had the following composition (\%): pork (53.5), beef (17.8), pork back fat (17.8), NaCl (2.8), sodium nitrate and sodium nitrite $(0.45)$, maltodextrins $(0.5)$, sodium eritorbate $(0.25)$, glucose (0.5), sucrose (0.5), skimmed milk powder (3.0), red wine and mixed spices. Sausages were prepared by grinding meat and pork back fat, and then adding the ingredients. After mixing, two batches were prepared: Batch A with the addition of $S$. xylosus U5 freeze-dried culture $\left(9 \mathrm{log}\right.$ cfu.g ${ }^{-1}$ of raw material) and Batch $B$ was used as the control (not inoculated), without selected starters. Batches were then stuffed into collagen casings 
(70 $\mathrm{mm}$ diameter). Afterwards, sausages with about $800 \mathrm{~g}$ each were transferred into a drying chamber and then kept under the following parameters of relative moisture and temperature during ripening, respectively: $25{ }^{\circ} \mathrm{C}$ and $95 \%$ (1st day), $24^{\circ} \mathrm{C} / 93 \%$ (2nd day), $23^{\circ} \mathrm{C} / 90 \%$ (3rd day), $22^{\circ} \mathrm{C} / 85 \%$ (4th day), $21^{\circ} \mathrm{C} / 80 \%$ (5th day), $20^{\circ} \mathrm{C} / 75 \%$ (6th day) and $18^{\circ} \mathrm{C} / 75 \%$ (7th day). These conditions were maintained for 42 days, the end of ripening.

\section{Sampling procedure}

Experiments were carried out for 42 days. Samples were randomly taken from each batch at $1,7,14$, 21,28 and 42 days for analyses.

\section{Microbiological analyses}

Microbiological analyses were carried out in order to monitor the dynamic changes during the storage of the sausages and their sanitary quality. In particular, $25 \mathrm{~g}$ of each sample were transferred into a sterile stomacher bag and $225 \mathrm{ml}$ of sterile $0.1 \%$ peptone water (Oxoid) were added and mixed for $1 \mathrm{~min}$ in a Stomacher machine (ITR, mod.MK 1204). Serial decimal dilutions in $0.1 \%$ peptone water were prepared and $1 \mathrm{~mL}$ or $0.1 \mathrm{~mL}$ samples of appropriate dilutions were poured or spread in duplicate. Analyses were carried out according to APHA (1992): (a) aerobic mesophilic counts were determined on plate count agar (PCA, Oxoid), incubated at $30^{\circ} \mathrm{C}$ for $48-72 \mathrm{~h}$; (b) $\mathrm{LAB}$ on MRS agar (Oxoid) incubated at $30^{\circ} \mathrm{C}$ for $72 \mathrm{~h}$ under anaerobic conditions; (c) coagulase-negative staphylococci (CNS) on BHI Agar (Oxoid) incubated at $35^{\circ} \mathrm{C}$ for $48 \mathrm{~h}$; (d) total coliforms on Brilliant Green Bile (2\%) Broth (Oxoid) after $48 \mathrm{~h}$ at $37^{\circ} \mathrm{C}$ ( MPN method); (e) thermotolerant coliforms on EC broth (Oxoid) incubated at $42^{\circ} \mathrm{C}$ for $24 \mathrm{~h}$ (MPN method); (f) Staphylococcus aureus on Baird-Parker medium (Oxoid) with egg yolk tellurite emulsion (Oxoid) incubated at $37^{\circ} \mathrm{C}$ for $24-48 \mathrm{~h}$; (g) yeasts and molds on glucose potato agar (Oxoid), supplemented with tetracycline (1 $\mathrm{mg} / \mathrm{mL}$, Sigma), incubated at $25^{\circ} \mathrm{C}$ for 5-7 days; (h) sulfite-reducing clostridia on agar and incubated anaerobically at $37^{\circ} \mathrm{C}$ for $48 \mathrm{~h}$. (i) for the detection of Salmonella, pre-enrichment was done by suspending $25 \mathrm{~g}$ of sample in $225 \mathrm{ml}$ buffered peptone water (Merck), followed by incubation at $37^{0} \mathrm{C}$ for $16-20 \mathrm{~h}$. Selective enrichment was done by transferring $0.1 \mathrm{~mL}$ of pre-enrichment culture in $10 \mathrm{~mL}$ Rappaport-Vassiliadis broth (RVS broth, Merck), followed by incubation at $42^{\circ} \mathrm{C}$ for $24 \mathrm{~h}$.
After incubation, samples were streaked on the modified BPLS agar, (Merck) $\left(37^{\circ} \mathrm{C}\right.$ for $\left.24 \mathrm{~h}\right)$ and XLD agar (Merck) $\left(37^{\circ} \mathrm{C}\right.$ for $\left.48 \mathrm{~h}\right)$; (j) for the detection of Listeria, enrichment was done by suspending $25 \mathrm{~g}$ of sample in $225 \mathrm{~mL}$ Fraser broth (Merck), followed by incubation at $30^{\circ} \mathrm{C}$ for $24 \mathrm{~h}$. Then, $0.1 \mathrm{~mL}$ of the culture enrichment were streaked on PALCAM agar (Merck) and incubated at $30^{\circ} \mathrm{C}$ for $48 \mathrm{~h}$. Tests were carried out in duplicate on two sausages and the results were expressed as $\log _{10}$ cfu.g ${ }^{-1}$ or MPN.g ${ }^{-1}$.

\section{Physicochemical analysis}

Samples were ground and blended in a grinder (Tecnal Turratec TE-102) and freeze-dried (Virtis Unitop/1000L). For monitoring the dynamic chemical changes, during and at the end of the fermentation/ripening process, the following analyses were performed (every 7 days): moisture (oven air-drying method), ash (muffle furnace), proteins (Kjeldhal nitrogen), fat (etheric extract), peroxide values, nitrite and nitrate content, acid value (\% lactic acid) were performed according to AOAC (2002). Iron and sodium analyses were carried out according to Granadillo et al. (1995). Approximately $500 \mathrm{mg}$ of samples were weighed into a digestion vessel $(22 \times 250 \mathrm{~mm})$, added 6.0 $\mathrm{mL}$ of $\mathrm{HNO}_{3}: \mathrm{HClO}_{4} 8: 1(\mathrm{v} / \mathrm{v})$ and heated as follows: $90{ }^{\circ} \mathrm{C} .30 \mathrm{~min}^{-1}$, rampered to $160{ }^{\circ} \mathrm{C} .40$ $\min ^{-1}\left(10^{\circ} \mathrm{C} \cdot \min ^{-1}\right), 180^{\circ} \mathrm{C} .20 \mathrm{~min}^{-1}$ and held this temperature until disappearing white steam. After digestion, $2.5 \mathrm{~mL}$ of $\mathrm{HCl}{ }_{(6 \mathrm{M})}$ were added and volume adjusted to $25 \mathrm{~mL}$. Iron $(\mathrm{Fe})$ was determined by flame atomic spectrometric analysis. For this, the diluted samples were directly aspirated into a spectrometer (Varian SpectrAA 220) equipped with lamp of hollow cathode, using air/acetylene flame. Sodium (Na) was determined by flame photometry (Micronal B262). Both, $\mathrm{Fe}$ and $\mathrm{Na}$, were quantified according to operating parameters provided by the respective equipment's manufacturer. Two independent measurements were made on each sample. Means and standard deviations were calculated.

\section{Free fatty acids (FFA) determination}

Samples were freeze-dried (Virtis Unitop/1000L) and lipids were extracted according to Folch et al, (1957). From this extract, an aliquot of $10 \mathrm{~mL}$ was taken and the total lipid content was determined gravimetrically. A further aliquot, containing approximately $100 \mathrm{mg}$ of lipid was esterified, and 
the fatty acid composition was determined by the gas chromatography (GC) (Shimadzu 2010). Dried lipid extract was esterified with a solution of ammonium chloride and sulfuric acid in methanol (Hartman and Lago, 1973). Fatty acid methyl esters were separated on a GC (Shimadzu 2010) system coupled to mass selective detector (Shimadzu QP2010). Separation was performed on a MS-5 capillary column (30 m;-0.25 mm I.D. $x$ $0.25 \mu \mathrm{m}$ film thickness) (Restec Rtx®). Carrier gas was helium with a linear flow rate of $1.0 \mathrm{~mL}$ $\min ^{-1}$. Temperature program was 150 to $220^{\circ} \mathrm{C}$ at $2^{0} \mathrm{C} \mathrm{min}{ }^{-1}$ and held for $15 \mathrm{~min}$. Samples of $1 \mu 1$ were injected in split less mode (100:1) and the injector temperature was set at $250^{\circ} \mathrm{C}$. Mass spectra were obtained under following conditions: $70 \mathrm{eV}$ in the $40-4000 \mathrm{u}$ range. Ion source was held at $220^{\circ} \mathrm{C}$ and quadrupole at $250^{\circ} \mathrm{C}$.

Fatty acids were identified by comparing the mass spectral data of sample components with those of known compounds from library databases (NIST05). Authentic standards of several detected compounds were analyzed in order to confirm the reliability of retention times and tentative identities, considering a similarity higher than $90 \%$. Results were expressed in \% of normalized area. Quantification was carried out by normalization and conversion of area percentage into g. $100 \mathrm{~g}^{-1}$ of edible portion, using the lipid conversion factor $(F)$. An F-value of 0.956 was used for processed meat products based on Holland et al. (1994). Two independent measurements were made on each sample. Means and standard deviations were calculated.

\section{Colour evaluation}

Colour evaluation was determined in Batch A and B of Milano salami type at the end of the maturation period, using a reflectance colorimeter (Chroma Meter CR-300, Minolta). CIE L* (lightness), $\mathrm{a}^{*}$ (redness), $\mathrm{b}^{*}$ (yellowness) colour values were measured. Colour readings were taken at three points of the cut surface of the two slices $(10 \mathrm{~mm})$. Six measurements were taken for each sample.

\section{Enterotoxin detection}

Enterotoxins were detected using the automated VIDAS instrument (bioMérieux) and a VIDAS ${ }^{\circledR}$ Staph enterotoxin SET 2 kit (bioMérieux). Extraction of enterotoxins (Batch A and B) was performed as described in the protocol for meat products according to manufacturer's instructions
(SET 2 kit). Relative fluorescence value (RFV) obtained was interpreted by VIDAS system as follows: negative when TV (Test Value) $<0.13$ and positive when $\mathrm{TV} \geq 0.13$.

\section{Sensorial analysis}

Sensorial analyses were carried out at the end of the ripening by a panel of 70 untrained panelists consisted of students and professors of Department of Science and Technology of Food. In order to evaluate the acceptance of sausages, tasters were asked to ordinate the samples from lower to higher preference (ABNT/NBR12994/1993 and NBR13170/1994). All the participants signed TCLE - Term of Free and Illustrious Consent, in accordance with the Project 189/05: Development of starter cultures for the production of artisanal sausages approved on June 27, 2005 for the Committee of Ethics in Research with Human beings of the Federal University of Santa Catarina, Brazil.

\section{Statistical analysis}

Data of physicochemical analyses are reported as mean values \pm standard deviation. To verify the differences among the sausages, results were submitted to the t-Test at 5\% level of confidence (STATISTICA 6.0).

\section{RESULTS AND DISCUSSION}

Results of microbiological analysis of the Milano salami type during the fermentation and ripening are presented in Figure 1. Initially, the counts of aerobic mesophilics were slightly lower in Batch B than in Batch A. After 14 days counts, the Batches $\mathrm{A}$ and $\mathrm{B}$ were significantly different $(\mathrm{P}<0.05)$, reaching 8.62 and $6.49 \log$ CFU.g ${ }^{-1}$, respectively. Gram-positive, catalase-positive cocci Coagulase-negative staphylococci (CNS) counts in the inoculated sample (Batch A) showed a substantial growth $(\mathrm{P}<0.05)$ of this group during the ripening. In Batch $\mathrm{A}$, initial count was of 7.60 $\log$ CFU.g ${ }^{-1}$, reaching $9.84 \log$ CFU.g ${ }^{-1}$ after 14 days. In control (Batch B), these microorganisms were found at very lower concentrations and after 14 days their number reached $6.95 \log$ CFU.g ${ }^{-1}$ (Fig.1). This substantial growth $(2 \mathrm{log})$ was due to lower concentrations of lactic acid bacteria (LAB) during the fermentation and ripening that reached at maximum levels of about $6.34 \mathrm{log}$ CFU.g ${ }^{-1}$ (Fig. 1c). However, sensibility of Micrococcaceae in the 
presence of high acidification was not affected (Palumbo and Smith, 1977); Lücke, 1985). In agreement with works of Comi et al., (1992) and Samelis et al., (1993), Micrococcaceae might become more competitive and reach 1-2 log higher counts in the case of a final $\mathrm{pH}$ above 5.5 in fermented sausages manufactured in artisanal scale. As LAB were not used as starter culture in the present work, their counts were not different between the control and inoculated batch. In fact, several species of LAB are part of the meat microflora.

The level of total and thermotolerant coliforms $(<3$ NMP) was similar in both the batches, but in the inoculated samples (Batch A), their number presented a sharp decrease. After 7 days of ripening, no viable cells of total and thermotolerant coliforms were detected. In control (Batch B), total coliforms were present even after 7 days and only after 21 days of ripening, their number decreased to undetectable levels. These results indicated that the strains of CNS were

a)

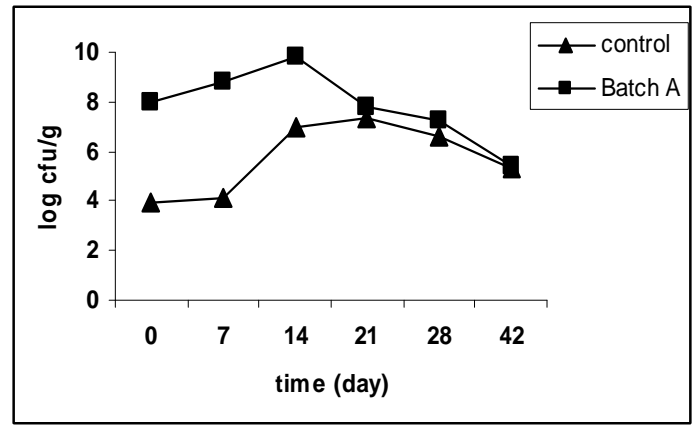

competitive and able to produce the antagonistic substances against the pathogenic bacteria, because in that period the counts of CNS in inoculated salami was around $8 \log \mathrm{cfu}^{-1}{ }^{-1}$. According to Pinto et al. (1998) and Essid et al. (2007) many strains of $S$. xylosus had antimicrobial activities against undesirable strains. Papamanoli et al. (2003) found that the once strains isolated from traditional sausages were well-adapted to sausages conditions, they were competitive. Nevertheless, both the coliforms were absent in the final product. Moulds and yeasts did not seem to play any significant role in sausages. Maximum counts of about $2.77 \mathrm{log}$ cfu.g $^{-1}$ were observed for them and were not detected in the most cases. These results met the requirement of the Brazilian legislation - sanitary microbiology patterns for ripening the meat product (BRASIL/ANVISA, 2001) - and confirmed the need of good manufacturing practices in order to obtain the reduced contamination of undesirable microorganisms.

b)

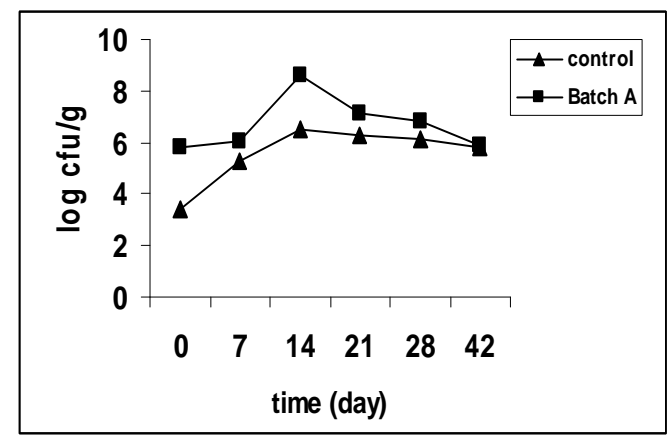

c)

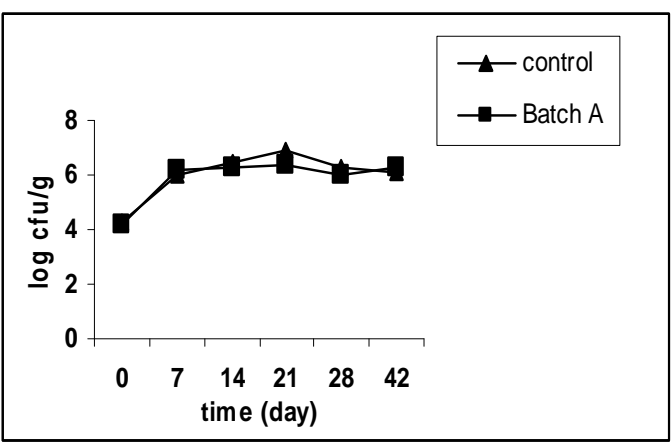

Figure 1 - Evolution of microflora during ripening of Milano salami. a) Gram-positive, catalasepositive cocci; b) mesophilic aerobic; c) lactic acid bacteria. 
Both the batches were free of Salmonella and Listeria after formulation, as well as the low number of sulfite-reducing clostridia $(<1)$ and coagulase positive staphylococci $(<2)$. These results also met the requirement of the legislation for fermented meat products during fermentation and in the final product. According to Drosinos et al. (2005), these results indicated the importance of selecting the raw materials of good microbiological quality for dry sausage manufacture.

Results of the physicochemical analyses of Milano salami type during fermentation and ripening are presented in Table 1. During the ripening, $\mathrm{pH}$ showed low variation among the batches (A and $\mathrm{B})$, probably due to low presence of $\mathrm{LAB}$, which were responsible for $\mathrm{pH}$ decrease and that the changes in $\mathrm{pH}$ due to Staphylococci were not significant. According to Olesen et al. (2004), Staphylococcus strains produce limited quantities of acid. The $\mathrm{pH}$ measured at the beginning of fermentation in both the batches was around 5.6 and decreased to around 5.2 after 7 days of ripening. A slight increase in $\mathrm{pH}$ was observed in the final product, with values around 5.3 in both the batches. These results were in agreement with those found for Galgano et al., (2003). This could be due to the production of ammonia and other basic compounds, such as peptides, amino acids, aldehydes, amines and free fatty acids arising from the proteolytic activity (Mauriello et al., 2004).

Table 1 - Changes in physical and chemical analysis during fermentation and ripening of Milano salami type

\begin{tabular}{|c|c|c|c|c|c|c|}
\hline Análises & Day $1^{0}$ & Day $7^{0}$ & Day $14^{0}$ & Day $21^{0}$ & Day $28^{0}$ & Day $42^{0}$ \\
\hline \multicolumn{7}{|l|}{ Moisture(\%) } \\
\hline Batch A & $52.8 \pm 0.43 a$ & $42.6 \pm 0.33 a$ & $42.5 \pm 0.35 \mathrm{a}$ & $40.5 \pm 0.27 \mathrm{a}$ & $35.9 \pm 0.10 \mathrm{a}$ & $28.4 \pm 0.08 \mathrm{a}$ \\
\hline Batch B & $52.4 \pm 0.30 \mathrm{a}$ & $44.0 \pm 0.28 \mathrm{a}$ & $41.7 \pm 0.45 a$ & $35.4 \pm 0.53 \mathrm{a}$ & $32.9 \pm 0.08 \mathrm{a}$ & $28.0 \pm 0.10 \mathrm{a}$ \\
\hline \multicolumn{7}{|l|}{$\operatorname{Ash}(\%)$} \\
\hline Batch A & $4.1 \pm 0.20 \mathrm{a}$ & $5.1 \pm 0.4 a$ & $5.2 \pm 0.10 \mathrm{a}$ & $5.4 \pm 0.01 \mathrm{a}$ & $5.8 \pm 0.06 \mathrm{a}$ & $6.2 \pm 0.30 \mathrm{a}$ \\
\hline Batch B & $4.6 \pm 0.10 \mathrm{a}$ & $5.0 \pm 0.4 \mathrm{a}$ & $5.3 \pm 0.38 \mathrm{a}$ & $5.8 \pm 0.27 \mathrm{a}$ & $5.8 \pm 0.12 \mathrm{a}$ & $6.4 \pm 0.80^{\mathrm{a}}$ \\
\hline \multicolumn{7}{|l|}{ Fat $(\%)$} \\
\hline Batch A & $21.9 \pm 0.37 \mathrm{a}$ & $25.0 \pm 0.03 \mathrm{a}$ & $24.1 \pm 0.20 \mathrm{a}$ & $24.6 \pm 0.04 a$ & $26.6 \pm 0.41 \mathrm{a}$ & $29.0 \pm 0.07 \mathrm{a}$ \\
\hline Batch B & $22.0 \pm 0.20 \mathrm{a}$ & $24.9 \pm 0.08 \mathrm{a}$ & $24.8 \pm 0.11 \mathrm{a}$ & $26.4 \pm 0.09 a$ & $28.1 \pm 0.15 a$ & $30.0 \pm 0.18 \mathrm{a}$ \\
\hline \multicolumn{7}{|l|}{$\operatorname{Protein}(\%)$} \\
\hline Batch A & $19.0 \pm 0.20 \mathrm{a}$ & n.d. & n.d. & n.d. & n.d. & $32.8 \pm 0.07 \mathrm{a}$ \\
\hline Batch B & $18.9 \pm 0.06 \mathrm{a}$ & n.d. & n.d. & n.d. & n.d. & $32.0 \pm 0.86^{\mathrm{a}}$ \\
\hline \multicolumn{7}{|l|}{$\mathbf{N a C l}(\%)$} \\
\hline Batch A & $3.2 \pm 0.00 \mathrm{a}$ & n.d. & n.d. & n.d. & n.d. & $4.8 \pm 0.12 \mathrm{a}$ \\
\hline Batch B & $3.2 \pm 0.03 \mathrm{a}$ & n.d. & n.d. & n.d. & n.d. & $4.9 \pm 0.01 \mathrm{a}$ \\
\hline \multicolumn{7}{|l|}{ aw } \\
\hline Batch A & $0.95 \pm 0.10 \mathrm{a}$ & $0.93 \pm 0.22 \mathrm{a}$ & $0.90 \pm 0.18 \mathrm{a}$ & $0.90 \pm 0.09 a$ & $0.87 \pm 0.18 \mathrm{a}$ & $0.82 \pm 0.06 \mathrm{a}$ \\
\hline Batch B & $0.96 \pm 0.07 \mathrm{a}$ & $0.93 \pm 0.35 \mathrm{a}$ & $0.90 \pm 0.27^{\mathrm{a}}$ & $0.90 \pm 0.13 \mathrm{a}$ & $0.87 \pm 0.28 \mathrm{a}$ & $0.83 \pm 0.31 \mathrm{a}$ \\
\hline \multicolumn{7}{|l|}{ pH } \\
\hline Batch A & $5.60 \pm 0.20 \mathrm{a}$ & $5.24 \pm 0.12 \mathrm{a}$ & $5.28 \pm 0.14 \mathrm{a}$ & $5.25 \pm 0.03 \mathrm{a}$ & $5.21 \pm 0.00 \mathrm{a}$ & $5.30 \pm 0.03 \mathrm{a}$ \\
\hline Batch B & $5.68 \pm 0.03 \mathrm{a}$ & $5.34 \pm 0.07 \mathrm{a}$ & $5.38 \pm 0.05^{\mathrm{a}}$ & $5.21 \pm 0.08 \mathrm{a}$ & $5.20 \pm 0.03 \mathrm{a}$ & $5.25 \pm 0.06^{\mathrm{a}}$ \\
\hline \multicolumn{7}{|l|}{$\mathbf{F e}\left(\mathrm{mg} \cdot 100 \mathrm{~g}^{-1}\right)$} \\
\hline Batch A & $1.0 \pm 0.08 \mathrm{a}$ & $1.2 \pm 0.55 \mathrm{a}$ & $1.4 \pm 0.78 \mathrm{a}$ & $1.2 \pm 0.02 \mathrm{a}$ & $1.2 \pm 0.05 \mathrm{a}$ & $1.5 \pm 0.10 \mathrm{a}$ \\
\hline Batch B & $1.0 \pm 0.09 \mathrm{a}$ & $1.1 \pm 0.10 \mathrm{a}$ & $1.1 \pm 0.80 \mathrm{a}$ & $1.2 \pm 0.75 \mathrm{a}$ & $1.2 \pm 0.06 \mathrm{a}$ & $1.7 \pm 0.08 \mathrm{a}$ \\
\hline \multicolumn{7}{|l|}{$\mathbf{N a}\left(\mathrm{mg} .100 \mathrm{~g}^{-1}\right)$} \\
\hline Batch A & $2049.3 \pm 1.90 \mathrm{a}$ & $2301.1 \pm 1.42 \mathrm{a}$ & $2427.0 \pm 0.96 a$ & $2483.2 \pm 0.88 \mathrm{a}$ & $2518.3 \pm 1.02 \mathrm{a}$ & $2522.7 \pm 0.66 a$ \\
\hline Batch B & $2061.2 \pm 2.10 \mathrm{a}$ & $2174.7 \pm 1.79 a$ & $2321.6 \pm 1.35 \mathrm{a}$ & $2476.5 \pm 1.98 \mathrm{a}$ & $2734.6 \pm 0.97 \mathrm{a}$ & $2865.9 \pm 1.11 \mathrm{a}$ \\
\hline \multicolumn{7}{|l|}{ lactic acid (\%) } \\
\hline Batch A & $0.26 \pm 0.03 \mathrm{a}$ & $0.57 \pm 0.02 \mathrm{a}$ & $0.64 \pm 0.09 \mathrm{a}$ & $0.7 .0 \pm 0.05 \mathrm{a}$ & $0.83 \pm 0.10 \mathrm{a}$ & $1.00 \pm 0.64 \mathrm{a}$ \\
\hline Batch B & $0.25 \pm 0.01 \mathrm{a}$ & $0.51 \pm 0.06 \mathrm{a}$ & $0.63 \pm 0.08^{\mathrm{a}}$ & $0.66 \pm 0.03 a$ & $0.86 \pm 0.03 a$ & $0.86 \pm 0.05 a$ \\
\hline \multicolumn{7}{|l|}{$\begin{array}{l}\text { Peroxide } \\
\left(\mathrm{mEq} \cdot \mathrm{kg}^{-1}\right)\end{array}$} \\
\hline Batch A & $0.65 \pm 0.03 \mathrm{a}$ & $0.73 \pm 0.07 \mathrm{a}$ & $1.29 \pm 0.05 \mathrm{a}$ & $1.48 \pm 0.05 \mathrm{a}$ & $2.07 \pm 0.03 \mathrm{a}$ & $2.86 \pm 0.06 \mathrm{a}$ \\
\hline Batch B & $0.66 \pm 0.02 \mathrm{a}$ & $0.95 \pm 0.05 b$ & $1.52 \pm 0.03 b$ & $2.23 \pm 0.00 \mathrm{~b}$ & $3.59 \pm 0.06 \mathrm{~b}$ & $3.89 \pm 0.02 b$ \\
\hline
\end{tabular}

Reported values are means of three replicates (assayed on 3 days and by three researchers).

Values in parenthesis on the left are standard deviations (S.D.) of three replicates

$\mathrm{a}, \mathrm{b}$ : values with different letter are significantly different $(\mathrm{P}<0.05)$. 
Water activity (aw) and moisture presented a constant decrease during the maturation (Table 1), while protein, fat, ash, $\mathrm{NaCl}, \mathrm{Na}$ and $\mathrm{Fe}$ content increased during the ripening because of the effect of dehydration. These results were in agreement with Brazilian legislation (BRASIL, 2000). The low amount of lactic acid (\%) (Table 1) was probably due to the activity of CNS that produced very limited amounts of acid or, yet, to the low presence of LAB.

Nitrate and nitrite are known as meat preservatives. Nitrate does not present antioxidant activity but becomes functional in nitrite reduction

a)

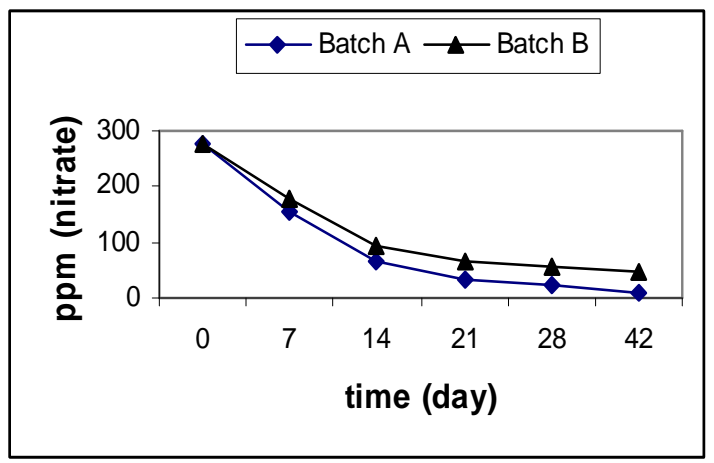

Figure 2 - Changes in nitrate and nitrite concentrations during fermentation and ripening of Milano salami type.
(Terra et al., 2004). During the fermentation and ripening nitrate is reduced to nitrite, which is the major active ingredient in salt mixtures (Cammack, 1999). Nitrate and nitrite levels decreased during the fermentation and ripening and concentrations were statistically different $(\mathrm{P}>$ 0.05) among the batches A and B (Fig. 2), probably due to the Micrococcaceae. Several studies have demonstrated that $S$. xylosus is able to reduce the nitrate by the secretion of a nitratoreductase (Montel et al., 1996; Talon et al., 1999; Mauriello et al., 2004; Fiorentini et al., 2009).

b)

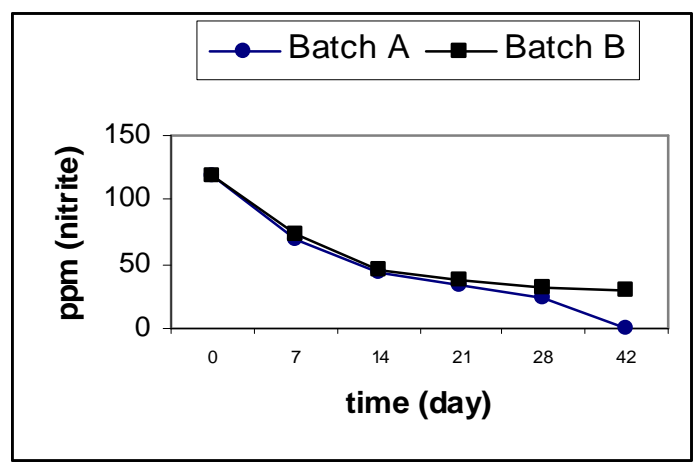

Nitrite concentrations needed for colour development range from 30 to $50 \mathrm{ppm}, 20$ to 40 ppm for aroma development, 80 to $150 \mathrm{ppm}$ for the conservative effect (Müller, 1991) and 20 to 50 ppm for the antioxidant effect, depending on the type of meat product (Lücke, 2000). In fermented products, nitrite is reduced to nitric oxide through the action of nitrite reductase, also present in the strains of the family Micrococcaceae. This reaction is faster in $\mathrm{pH}$ above 5.6 and slower in $\mathrm{pH}$ higher than 6.2 (Arnau et al., 1998). For the nitrite reductase enzyme to act as reducer agent, the counts of Micrococcaceae should be close to $6 \log$ CFU.g ${ }^{-1}$ (Campbell-Platt and Cook, 1995). During the fermentation and ripening, the decrease in nitrite concentration in both batches could be due to the action of a nitrite-reductase enzyme secreted by the Micrococcaceae, being more pronounced in batch A (7 to 28 days) (Fig. 2), where the Grampositive cocci counts were higher than 6 log.UFC.g-1. In batch B, the decrease of nitrite concentration appeared only after the 14th day (Fig. 1). Nitrite reduction capacity is another characteristic of Micrococcaceae demonstrated by the absence of nitrosamines in fermented meat products (Pinto et al., 2001).

The peroxide value was also determined in this work. During the ripening, low peroxide values were observed in batch $\mathrm{A}$ when comparing to batch $B$, which were significantly different $(\mathrm{P}<0.05)$, demonstrating the catalase activity of $S$. xylosus U5. Lipid oxidation leads to the formation of peroxides which are reduced in the presence of microorganisms with high catalase activity (Varnan and Sutherland, 1995). Catalase activity is important due to its capacity of reducing hydrogen peroxide, which can be formed as a metabolite by LABs and other bacterial species in sausages.

According to Cornforth (1996), nitrite has also an effect in inhibiting the development of rancidity. Traditional meat products, such as dry fermented sausages are interesting models for investigations, 
once they are exposed to pro-oxidant conditions. Peroxide values were around 2-4 mequivO $\mathrm{Fg}_{2} \mathrm{~kg}^{-1}$, acceptable levels for a good quality (Fernández and Rodríguez, 1991; Johansson et al., 1994; Ghiretti et al., 1997; Novelli et al., 1998; Zanardi et al., 1998).

The free fat acids found were C14:0; C16:0; C16:1 (9); C17:0; C18:0; C18:1 (9); C18:1 (11); C18:2 $(9,12)$, (Table 2). In both the batches, a progressive increasing was observed in free fatty acid production during the ripening, but no significant differences $(\mathrm{P}>0.05)$ were noticed among the batches. Even considering that Staphylococcus strains played an important role in lipolysis (Samelis et al., 1993), the values indicated that the S. xylosus strain U5 did not act significantly in the chemical transformations of lipids. Similar results were reported by Montel et al., (1993) where the batch inoculated with Staphylococcus presented fatty acid content similar to control (without addition of starter cultures). In this case, lipolytic processes were not attributed to the Staphylococcus strain. Molly et al., (1997), studying lipolysis, showed that the bacterial activity in sausages was low, once environmental conditions did not offer favorable conditions for bacterial lipases. Stahnke (1994), on the other hand, reported that more than $60 \%$ of free fatty acids were released in the sausages with the addition of $S$. xylosus strains. This indicated that $S$. xylosus strains were lipolytic as reported in several studies (Comi et al., 1992; Sorensen et al., 1993). Although several bacteria selected due to their lipolytic activity are used as commercial starter cultures, the addition of lipases frequently do not affect the sensorial evaluation of the fermented sausages (Fernández et al., 1991). Besides, bacterial lipolytic activity is influenced by several factors, such as the physiological state of culture, substrate type, $\mathrm{pH}$, temperature, etc. (Talon et al., 1992). Although S. xylosus U5 strain had presented lipolytic activity (Fiorentini et al., 2009), low activity was observed under the conditions found in Milano salami type. Galgano et al., (2003) and Zuber et al., (2007) did not observe any significant change on fatty acids content when evaluating the influence of several strains of S. xylosus in sausage.

Relative percentages of free fatty acids (FFA) after 40 days of ripening are presented in Figure 3. When comparing with control (Batch B), the addition of starter cultures (Batch A) did not cause significant modifications in relative percentages of FFAs. In both the batches, monounsaturated fatty acids were predominant, with a content of $46.99 \%$ in batch A and $45.08 \%$ in batch B, and oleic acid (C18:1) was found in highest concentrations (9.37\%), followed by palmitoleic acid (C16:1) $(7.81 \%)$. Polyunsaturated fatty acids were found in low concentrations. Free unsaturated fatty acids are important precursors of flavour in fermented ripened meat products (Molly et al., 1997; Chizzolini et al., 1998). The contents of saturated fatty acids (SFF) were 37.38 and $39.92 \%$ for batch $\mathrm{A}$ and $\mathrm{B}$, respectively, with palmitic acid (C16:0) and stearic acid (C18:0) representing the highest contents. A reduced content of SFF is desirable in the foods, as they influence the level of blood cholesterol. Similar results were reported for Milano salami (Zanardi et al., 2002; Campos et al., 2006) and for other types of fermented sausages similar to Milano type in ripening time (Domínguez-Fernández e Zumalacárregui, 1991; Hierro et al., 1997; Galgano et al., 2003; Zuber et al., 2007).

Regarding the colour parameters obtained for the Milano salami, significant differences $(P<0.05)$ were observed between the batches $\mathrm{A}$ and $\mathrm{B}$. Batch A showed significantly higher $L^{*}, a^{*}$ e $b^{*}$ values in relation to control (Batch $\mathrm{B}$ ), probably due to enzymatic action of the added strain of $S$. xylosus U5 (Table 2). This enzymatic action concerns to nitrate-reductase activity that leads to the formation of nitrosomyoglobin (Talon et al., 1999). Dellaglio et al. (1996), studying an Italian dry-cured sausage (Felino salami), found similar $\mathrm{L}^{*}$ values $(39.10 \pm 47.27)$ and higher $\mathrm{a}^{*}$ values $(22.13 \pm 30.08)$, but lower $b^{*}$ values $(5.68 \pm 8.90)$. Pagan-Moreno et al. (1992), in chorizo, found lower values for $\mathrm{L}^{*}(34.72 \pm 41.53)$ and $\mathrm{a}^{*}(13.87 \pm$ $17.55)$, being $b^{*}$ values more similar to that found in the present work $(9.33 \pm 14.10)$. In meat and meat products, lightness $\left(\mathrm{L}^{*}\right)$ seems to be the most informative parameter for color changes (Mielnik and Slinde, 1983) but the importance of red (a*) should not be ignored (Ferreira, Fernandes and Yotsuyanagi, 1994). Chouliara et al., (2006) studied the different factors of action in sausage color: irradiation effect at the end of ripening period of Greek dry fermented sausage (28 days), ands found that the irradiation had little or no effect at the end of ripening on $\mathrm{pH}$, moisture content and color (parameters $\mathrm{L}^{*}, \mathrm{a}^{*}$, and $\mathrm{b}^{*}$ ). 
Table 2 - Evolution of fatty acids content during fermentation and ripening of Milano salami type.

\begin{tabular}{|c|c|c|c|c|c|c|c|}
\hline \multirow{2}{*}{$\begin{array}{c}\text { Fatty acid } \\
\left({\left.\text { g. } 100 g^{-1}\right)}^{-1}\right.\end{array}$} & \multirow{2}{*}{ Batch } & \multicolumn{6}{|c|}{ Time/day } \\
\hline & & 1 & 7 & 14 & 21 & 28 & 42 \\
\hline \multirow[t]{2}{*}{ C14:0 } & A & $0.32 \pm 0.03 a$ & $0.36 \pm 0.04 a$ & $0.38 \pm 0.07 \mathrm{a}$ & $0.36 \pm 0.01 \mathrm{a}$ & $0.39 \pm 0.11 \mathrm{a}$ & $0.42 \pm 0.01 \mathrm{a}$ \\
\hline & $\mathrm{B}$ & $0.31 \pm 0.06 a$ & $0.35 \pm 0.08 \mathrm{a}$ & $0.36 \pm 0.00 \mathrm{a}$ & $0.40 \pm 0.25 a$ & $0.43 \pm 0.03 \mathrm{a}$ & $0.42 \pm 0.08 \mathrm{a}$ \\
\hline \multirow[t]{2}{*}{ C16:0 } & A & $5.17 \pm 0.16 \mathrm{a}$ & $5.70 \pm 1.28 \mathrm{a}$ & $5.80 \pm 0.09 a$ & $5.72 \pm 1.29 a$ & $6.31 \pm 0,74 a$ & $6.52 \pm 1.35 \mathrm{a}$ \\
\hline & B & $5.07 \pm 0.16 a$ & $5.69 \pm 1.03 a$ & $5.78 \pm 0.25 \mathrm{a}$ & $6.16 \pm 1.51 \mathrm{a}$ & $6.74 \pm 0,06 a$ & $7.13 \pm 0.38 \mathrm{a}$ \\
\hline \multirow[t]{2}{*}{ C 17:0 } & A & $0.09 \pm 0,01 \mathrm{a}$ & $0.10 \pm 0.02 \mathrm{a}$ & $0.05 \pm 0.04 a$ & $0.05 \pm 0.01 \mathrm{a}$ & $0.06 \pm 0.01 \mathrm{a}$ & $0.12 \pm 0.05 a$ \\
\hline & B & $0.09 \pm 0,01 \mathrm{a}$ & $0.10 \pm 0.01 \mathrm{a}$ & $0.06 \pm 0.01 \mathrm{a}$ & $0.07 \pm 0.00 \mathrm{a}$ & $0.05 \pm 0.00 \mathrm{a}$ & $0.07 \pm 0.01 \mathrm{a}$ \\
\hline \multirow[t]{2}{*}{ C18:0 } & A & $2.79 \pm 0.45 \mathrm{a}$ & $3.03 \pm 0.99 a$ & $2.84 \pm 0.07 \mathrm{a}$ & $3.03 \pm 0.69 \mathrm{a}$ & $3.42 \pm 0.04 \mathrm{a}$ & $3.35 \pm 1.03 \mathrm{a}$ \\
\hline & $\mathrm{B}$ & $3.08 \pm 0.05 \mathrm{a}$ & $3.12 \pm 0.26 \mathrm{a}$ & $3.05 \pm 0.50 \mathrm{a}$ & $3.32 \pm 0.15 \mathrm{a}$ & $3.54 \pm 0.06 \mathrm{a}$ & $3.38 \pm 0.25 \mathrm{a}$ \\
\hline \multirow[t]{2}{*}{ C16:1(9) } & A & $0.42 \pm 0.03 a$ & $0.46 \pm 0.11 \mathrm{a}$ & $0.47 \pm 0.06 a$ & $0.46 \pm 0.09 a$ & $0.49 \pm 0.01 \mathrm{a}$ & $0.55 \pm 0.08 \mathrm{a}$ \\
\hline & B & $0.39 \pm 0.03 a$ & $0.36 \pm 0.06 a$ & $0.47 \pm 0.02 \mathrm{a}$ & $0.50 \pm 0.09 a$ & $0.53 \pm 0.02 \mathrm{a}$ & $0.55 \pm 0.01 \mathrm{a}$ \\
\hline \multirow[t]{3}{*}{ C18:1(9) } & A & $8.62 \pm 0.65 a$ & $9.39 \pm 2.09 \mathrm{a}$ & $9.61 \pm 0.23 a$ & $9.33 \pm 3.02 \mathrm{a}$ & $10.52 \pm 0.04 \mathrm{a}$ & $11.18 \pm 2.03 \mathrm{a}$ \\
\hline & $\mathrm{B}$ & $9.77 \pm 0.01 \mathrm{a}$ & $9.82 \pm 0.11 \mathrm{a}$ & $9.93 \pm 0.34 \mathrm{a}$ & $10.32 \pm 0.49$ & $11.22 \pm 0.04 \mathrm{a}$ & $12.12 \pm 0.42 \mathrm{a}$ \\
\hline & & & & & $\mathrm{a}$ & & \\
\hline \multirow{3}{*}{ C18:1(11) } & B & $0.69 \pm 0.04 a$ & $0.67 \pm 0.08 a$ & $\begin{array}{l}0.01 \pm 0.23 \mathrm{a} \\
0.68 \pm 0.02 \mathrm{a}\end{array}$ & $0.65 \pm 0.16 a$ & $0.76 \pm 0.1 / \mathrm{a}$ & $\begin{array}{l}0.8 \angle \pm 0.00 a \\
0.87+0.01 \mathrm{a}\end{array}$ \\
\hline & & & & & $0.72 \pm 0.50 a$ & & \\
\hline & A & $2.10 \pm 0.38 \mathrm{a}$ & $2.65 \pm 0.78 a$ & $2.76 \pm 0.43 a$ & & $2.62 \pm 0.21 \mathrm{a}$ & $2.17 \pm 0.87 \mathrm{a}$ \\
\hline C18:2(9, 12) & $\mathrm{B}$ & $2.57 \pm 0.09 a$ & $2.75 \pm 0.06 a$ & $2.66 \pm 0.21 \mathrm{a}$ & $\begin{array}{l}2.37 \pm 1.17 \mathrm{a} \\
2.78 \pm 0.78 \mathrm{a}\end{array}$ & $2.92 \pm 0.40 \mathrm{a}$ & $2.70 \pm 0.36^{\mathrm{a}}$ \\
\hline
\end{tabular}

Values with same letter, in the same column, did not present significant difference $(\mathrm{P}<0.05)$.

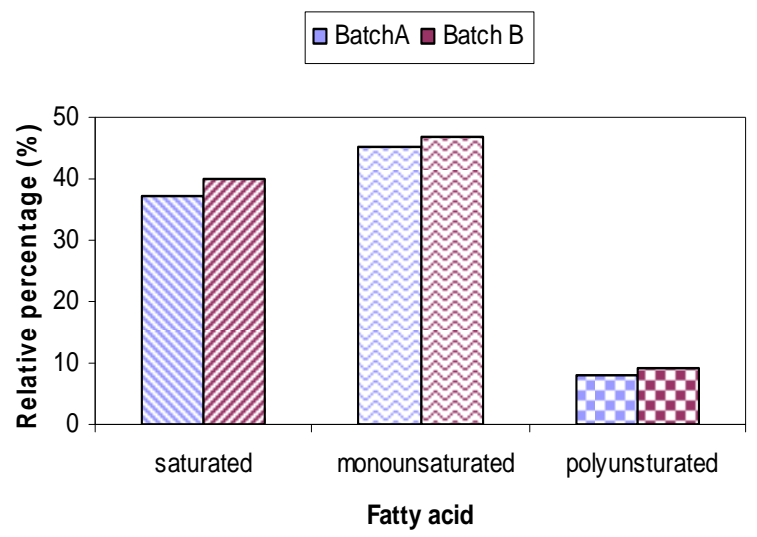

Figure 3 - Fatty acid compositions in Milano salami type: relative percentage after 40 days of ripening.

Table 3 - CIE L*, a*, b* parameters in Milano salami after 40 days of ripening ${ }^{\mathrm{a}}$.

\begin{tabular}{llll}
\hline & $\mathrm{L}^{*}$ & $\mathrm{a}^{*}$ & $\mathrm{~b}^{*}$ \\
\hline Batch A (S.xylosus U5) & $49.46(1.90) \mathrm{a}$ & $18.26(0.78) \mathrm{a}$ & $9.79(0.90) \mathrm{a}$ \\
Batch B (control) & $42.27(1.21) \mathrm{b}$ & $13.59(0.81) \mathrm{b}$ & $8.06(0.61) \mathrm{b}$ \\
\hline
\end{tabular}

\footnotetext{
${ }^{\mathrm{a}}$ Mean values (with standard deviation in the parentheses)
}

$\mathrm{a}, \mathrm{b}$ : columns with different letter differ significantly $(\mathrm{P}<0.05)$ 
In the present work, staphylococcal enterotoxins were not found in Milano salami type in both the batches (A and B), rejecting the possibility of enterotoxin production by the inoculated strain $S$. xylosus U5 or by any CNS present in the product, confirming it as a safe product for consumption. Staphylococcal food poisoning occurs by ingestion of the pre-formed enterotoxins in consequence of human manipulation or raw material derived from the contaminated animals. Cunha et al., (2006) evaluated 88 food samples and 4 CNS isolates by PCR and found them positives for the genes that codified the enterotoxins but none enterotoxin production was detected by RPLA method. Very little, however, is known about the growth of CNS in food. Pereira and Pereira (2006), in agreement with results found in the present work, reported that none out of 266 CNS isolates produced enterotoxins and $90 \%$ of the 252 identified CNS isolates were S. xylosus and S.carnosus.

The sensorial evaluation indicated the preference for the inoculated sausage $(72.5 \%)$. S. xylosus U5 strain had an enzymatic profile capable of producing desirable sensorial properties in the meat products increasing the product acceptability. Hence, the sensorial quality of the final product is affected by the type of starter culture used in formulation (Berdagué et al., 1993). Micrococcaceae are the main species that contribute in the formation of colour and flavor in the meat products (Montel et al., 1996; Stahnke et al., 2002). These two characteristics are very important for the acceptability of sausages.

S. xylosus strain U5 presented a good development during the fermentations and ripening of Milano salami type. Bacterial enzymes that showed efficient activity under the conditions found in the sausage were catalase, nitrate and nitrite reductase, contributing for the sensorial and physicochemical properties of the product. Colour parameters were higher in the inoculated salami being preferred by the tasters in the sensorial analysis, but no significant differences were observed in general fatty acid composition. S. xylosus strain U5 could be used as a single starter culture in fermented sausages or mixed with LAB as the results obtained for synergism suggested. However, additional studies would be needed in order to evaluate the technological properties of wild strains of S. xylosus in fermented sausages.

\section{ACKNOWLEDGEMENTS}

This work was supported by EMBRAPA, Brazil.

\section{RESUMO}

A análise da influência de culturas iniciadoras nativas nas características microbiológicas, físicoquímicas e sensoriais de salame tipo Milano foi o objeto deste estudo. Foram produzidos dois grupos de salame tipo Milano: Grupo A - com aplicação de linhagem Staphylococcus xylosus U5 enquanto o controle, Grupo B, foi produzido sem culturas iniciadoras. $\mathrm{O}$ salame tipo Milano foi caracterizado pela importante atividade microbiana de estafilococos coagulase negativo (SCN), que resultou significativo crescimento no Grupo A durante a maturação, com contagem inicial de 7,60 ufc. g $^{-1}$ e alcançando um crescimento de 9,84 cfu.g ${ }^{-1}$ depois de 14 dias. As enzimas bacterianas que mostraram eficiente atividade sob as condições encontradas no salame tipo Milano foram catalase, nitrito e nitrato redutase, contribuindo para as propriedades físicoquímicas e sensoriais do produto. Não houve diferenças significativas na composição geral dos ácidos graxos livres entre as amostras, enquanto os parâmetros de cor $\left(L^{*}, a^{*}\right.$ e b*) obtidos no salame inoculado (Grupo A) diferiram significativamente em relação ao controle (Grupo B) e foi o grupo preferido pelos degustadores.

\section{REFERENCES}

ABNT - ASSOCIAÇÃO BRASILEIRA DE NORMAS TÉCNICAS (1993), Métodos de análise sensorial de alimentos e bebidas. NR 12994. ABNT: Rio de Janeiro.

BNT - ASSOCIATION BRASILEIRA DE NORMAS TÉCNICAS (1994), Teste de ordenação em análise sensorial. NR 13170. ABNT: Rio de Janeiro.

AOAC (2002), Official methods of Analysis (17th ed.). Washington, DC: Association of Official Analytical Chemists.

AMERICAN PUBLIC HEALTH ASSOCIATION (1992), Compendium of methods for the microbiological examination of food. 3. ed. Washington: APHA. 
Arnau, J. et al., (1998), The effect of green ham $\mathrm{pH}$ and $\mathrm{NaCl}$ concentration on cathepsin activities and the sensory characteristics of dry-cured Hams. Journal Science Food Agriculture, 77, 387-392,

Aymerich, M.T., Garriga, M., Monfort, J.M., Nes, I. and Hugas, M. (2000), Bacteriocin-producing lactobacilli in Spanish-style fermented sausages: characterization of bacteriocins. Food Microbiol. 17, 33-45.

Barriére, C. et al., (2001), Roles of superoxide dismutase and catalase of Staphylococcus xylosus in the inhibition of linoleic acid oxidation. FEMS Microbiology Letters, 201, 181-185.

Berdagué, J.L., Monteil, P., Montel, M. C. and Talon, R. (1993), Effects of starter cultures on the formation of flavour compounds in dry sausage. Meat Science, 35(3), 275-287.

Bover-Cid, S., Izquierdo-Pulido, M. and Vidal-Carou, M.C. (1999), Effect of proteolytic starter cultures of Staphylococcus spp. on biogenic amine formation during the ripening of dry fermented sausages. Int. J. Food Microbiol. 46, 95-104.

Bover-Cid, S., Hugas, M., Izquierdo-Pulido, M. and Vidal-Carou, M.C. (2001), Amino aciddecarboxylase activity of bacteria isolated from fermented pork sausages. Int. J. Food Microbiol. 66, 185-189.

BRASIL, (2000), Ministério da Agricultura, Pecuária e Abastecimento - MAPA/ Secretaria de Defesa Agropecuária. Instrução Normativa $\mathrm{N}^{\mathrm{o}} 22$ de 31 de julho de 2000: Anexo V - Regulamento Técnico de Identidade e Qualidade de Salame. Disponível em: <http://extranet.agricultura.gov.br/consultasislegis>. Acesso em 14 de abril 2007.

BRASIL, (2000), Instrução Normativa $n^{\circ} 22$, de 31 de julho de 2000 - Anexo XIII. Regulamentos Técnicos de Identidade e Qualidade de Salame Tipo Milano. Publicada no Diário Oficial da União de 03/08/2000.

BRASIL, (2001), Ministério da Saúde - MS/Agência Nacional de Vigilância Sanitária - ANVISA. Resolução No 12 de 02 de janeiro de 2001 Regulamento Técnico sobre padrões microbiológicos para alimentos. Disponível em: <http://www.anvisa.gov.br/e-legis > Acesso em 06 de março de 2007.

Cammack, R. et al., (1999), Nitrite and nitrosyl compounds in food preservation. Biochimica et Biophysica Acta, 1411, 475 - 488.

Campbell-Platt, G. and Cook, P.E. (1995), Bacterial fermentation of meats. Fermented Meats. London, UK: Chapman and Hall, 69-109.

Campos, R.M.L. et al., (2006), A note on partial replacement of mayze with rice bran in the pig diet on meat and backfat acids. Journal of Animal and Feed Sciences, 15, 427-433.
Chizzonilin, R., Novelli, E. and Zanardi, E. (1998), Oxidation in traditional mediterranean meat products. Meat Science, 49 (1), 87 - 99.

Chouliara, I., Samelis, J., Kakouri, A., Badeka, A., Savvaidis, I.N., Riganakos, K. and Kontominas, M.G. (2006), Effect of irradiation of frozen meat/fat trimmings on microbiological and physicochemical quality attributes of dry fermented sausages. Meat Science, 74, 303-311.

Cocolin, L., Manzano, M., Aggio, D., Cantoni, C., and Comi, G. (2001), A novel polymerase chain reaction (PCR)-denaturing gradient gel electrophoresis (DGGE) for the identification of Micrococcaceae strains involved in meat fermentations. Its application to naturally fermented Italian sausages. Meat Science, 57, 59-64.

Comi, G., Citterio, B., Manzano, M., and Cantoni, C. (1992), Evaluation and characterization of Micrococcaceae strains in Italian dry fermented sausages. Fleischwirtschaft, 72, 1679-1683.

Cornforth, D. P. (1996), Role of nitric oxide in treatment of foods. In: Lancaster, J. R. (Ed.). Nitric oxide: Principles and actions. San Diego: Academic Press, $259-287$.

Coppola, R., Iorizzo, M., Saotta, R., Sorrentino, E., and Grazia, L. (1997), Characterization of micrococci and staphylococci isolated from soppressata molisana, a Southern Italy fermented sausage. Food Microbiology, 14, 47-53.

Coventry, J. and Hickey, M.W., (1991), Growth characteristics of meat starter cultures. Meat Science 30, 41- 48 .

Cunha, M.L.R.S. et al., (2006), Detection of enterotonins genes in coagulase-negative Staphylococci isolated from foods. Brazilian Journal of Microbiology, 37: 70-74.

Dellaglio, S., Casiraghi, E. and Pompei, C. (1996), Chemical, physical and sensory attributes for the characterization of an Italian dry-cured sausage. Meat Science, 42, 25-35.

Domínguez Fernández, M. C. and Zumalacárregui Rodríguez, J. M. (1991), Lipolytic and oxidative changes in "chorizo" during ripening. Meat Science, 29, 99-107.

Drosinos, E.H., Mataragas, M., Xiraphi, N., Moschonas, G., Gaitis, F. and Metaxopoulos, J. (2005), Characterization of the microbial flora from a traditional Greek fermented sausage. Meat Sci. 69, 307-317.

Drosinos, E.H., Paramithiotis, S., Kolovos, G., Tsikouras, I. and Metaxopoulos, I. (2007), Phenotypic and technological diversity of lactic acid bactéria and staphylococci isolated from traditionally fermented sausages in Southern Greece. Food microbiology, 24, 260-270. 
Essid, I., Ismail, H.B., Hadj Ahmed, S.B., Ghedamsi, R. and Hassouna, M. (2007), Characterization and technological properties of Staphylococcus xylosus strains isolated from a Tunisian traditional salted meat. Meat Sci. 77, 204 - 212.

Fadda, S., Vignolo, G., Holgado, A.P.R. and Oliver, G. (1998), Proteolytic activity of Lactobacillus strains isolated from dry-fermented sausages on muscle sarcoplasmic proteins. Meat Sci. 49, 1-18.

Fernandez, M., Diaz, O., Cambero, M. I., Hoz, L. and Ordonez, J. A. (1991), Proc. 37nd ZCoMST, Kulmbach, p. 867.

Fernandez, M. and Rodriguez, J. (1991), Lipolytic and oxidative changes in chorizo during ripening. Meat Science, 29, 99-107.

Ferreira, V. L. P., Fernandes, S. V. and Yotsuyanagi, K. (1994), The color of chicken and pork meat loaf with added cured bovine blood a evaluated by the Rab, Hunter Lab, L*, a*, b* and XYZ CIE systems. Revista Española de Ciencia y Tecnología de Alimentos, 34, 11-32.

Fiorentini, A.M. et al., (2009), Phenotypic and molecular characterization of Staphylococcus xylosus: Technological potencial for use in fermented sausage. Braz. Arch. of Biol. and Technol. 52, n.3, 737-746.

Folch, J., Less, M. and Stanley, S. (1957), A simple method for the isolation and purification of total lipids from animal tissues. Journal of Biological Chemistry, 226, 497-509.

Forrest, J.C. et al., (1979), Fundamentos de ciencia de la carne. Traduzido por: Bernabé Sanz Pérez. Zaragoza: Acribia, p.364.

Galgano, F., Favati, F., Schirone, M., Martuscelli, M. and Crudele, M.A. (2003), Influence of Indigenous Starter Cultures on the Fatty Acids Content During Ripening in Artisan Sausges Produced in the Basilicata Region. Food Technol. Biotechnol., 47 (3) 253-258.

Garcia-Varona, M., Santos, E.M., Jaime, I. and Rovira, J., (2000), Characterisation of Micrococcaceae isolated from different varieties of chorizo. Int. J. Food Microbiol. 54, 189-195.

Geisen, R., Lücke, F.K. and Kröckel, L. (1992), Starter and protective cultures for meat and meat products. Fleischwirtschaft, 72, 894-898.

Guiretti, G.P. et al., (1997), Comparative evaluation of some antioxidants in salame Milano and mortadella production. Meat Science, 47, n. 1/2, 167 - 176.

Granadillo, V.A. et al., (1995), Three pressurized mineralization procedures that permit subsequent flame atomic spectrometric determination of $\mathrm{Ca}, \mathrm{Fe}$, $\mathrm{K}, \mathrm{Kg}$ and $\mathrm{Zn}$ in bovine blood plasma-containing cookies and in standard reference materials. Analytica Chimica Acta, 306, 139 -147.
Hammes, W.P. (1990) Bacterial starter cultures in food production. Food Biotechnol. 4, 383-397.

Hartman, L. and Lago, R. C. A. (1973), Rapid preparation of fatty acid methyl esters from lipids. Laboratory Practies, 22, 475-481.

Hierro, E., Hoz, L. and Ordónez, J.A. (1997), Contribution of microbial and meat endogenous enzymes to the lipolysis of dry fermented sausages $J$ Agric Food Chem. 45, 2989-2995.

Holland, B., Welch, A. A., Unwin, I. D., Buss, D. H., Paul, A. A. and Southgate, D. A. T. (1994), McCance and Widdowsons. The composition of foods (5th ed., pp. 8-9) London: The Royal Society of Chemistry and Ministry of Agriculture, Fisheries and Food.

Jessen, B. (1995), Starter cultures for meat fermentation. In: G. Campbell-Plat e P.E.Cook (Eds.), Fermented meats, Glasgow Blackie Academic and Professional, 130-154.

Johansson, G. et al., (1994). Lipolysis, proteolysis and formation of volatile components during ripening of a fermentation sausage with Pediococcus pentosaceus and Staphylococcus xylosus as starter cultures. Meat Science, 38, $203-218$.

Lücke, F.K. and Hechelmann, H. (1987), Starter cultures for dry sausages and raw ham. Composition and effect. Fleischwirtschaft 67, 307-314.

Lücke, F.K. (1985), Fermented sausages. In: B.J.B. Wood (Ed.), Microbiology of Fermented Foods, Elsevier, London and New York, p. 41-83.

Lücke, F.K. (2000), Use of nitrite and nitrate in the manufacture of meat products. Fleischwirtschaft International, 4, 38-41.

Martuscelli, M., Crudele, M.A., Gardini, F. and Suzzi, G. (2000), Biogenic amine formation and oxidation by Staphylococcus xylosus strains from artisanal fermented sausages. Lett. Appl. Microbiol. 31, 228232.

Mauriello, G., Casaburi, A., Blaiotta, G. and Villani, F. (2004), Isolation and technological properties of coagulase negative staphylococci from fermented sausages of Southern Italy. Meat Sci. 67, 149-158.

Messens, W., Verluyten, J., Leroy, F. and De Vuyst, L. (2003), Modelling growth and bacteriocin production by Lactobacillus curvatus LTH 1174 in response to temperature and $\mathrm{pH}$ values used for European sausage fermentation processes. Int. J. Food Microbiol. 81, 41-52.

Mielnik, J. and Slinde, E. (1983), Sausage color measured by integrating sphere re-ectance spectrophotometry when whole bood or blood cured by nitrite is added to sausages. Journal of Food Science, 48, 1723-1725.

Molly, K., Demeyer, D., Civera, T. and Verplaetse, A. (1996), Lipolysis in a Belgian sausage: Relative Importance of Endogenous and Bacterial Enzymes. Meat Sci 43, 235-244 
Molly, K. et al., (1997), The importance of meat enzymes in ripening and flavour generation in dry fermented sausages: first results of a European project. Food Chemistry, 59, (4), 539 - 545.

Montel, M.C., Talon, R., Cantonnet, M. and Fournaud, J. (1992), Identification of Staphylococcus from French dry sausage. Letters in Applied Microbiology 15, 73-77.

Montel, M.C., Talon, R., Berdagué, J. L. and Cantonnet, M. (1993), Effects of starter cultures on the biochemical characteristics of frensch dry sausages. Meat Science, 35, 229-240.

Montel, M.C., Reitz, J., Talon, R., Berdague, J.L. and Rousset-Akrim, S. (1996), Biochemical activities of Micrococcaceae and their effects on the aromatic profiles and odours of a dry sausage model. Food Microbiology 13, 489-499.

Müller, W.D. (1991), Curing nas smoking: are they healthier processes today than used to be? Fleischwirtschaft, v.71, n.1, p.61-65.

Novelli, E. et al., (1998), Lipid and cholesterol oxidation in fronzen stored pork, salame Milano and mortadela. Meat Science, 48 (1/2), 29 - 40.

Novelli, E., Zanardi, E., Ghiretti, G.P. et al., (1998), Lipid and cholesterol oxidation of frozen stored pork, salame Milano and mortadella. Meat Scince, 48, 2940.

Olesen, P. T., Meyer, A. S. and Stahnke, L. (2004), Generation of flavour compounds in fermented sausages - the influence of curing ingredients, Staphylococcus starter culture and ripening time. Meat Science, 66, 675 - 687.

Ordóñez, J.A., Rodríguez, M.I.C., Alvárez, L.F. et al., (2005), Tecnologia de Alimentos - Alimentos de Origem Animal. v.2 Traduzido por: MURAD, F. Porto Alegre: Artmed, p.279.

Pagan-Moreno, M. J. et al., (1992), Chorizo: color parameters evolution during ripening. In 38th International congress of meat science and technology. France. Clermont-Ferrand. 563-566.

Palumbo, S.A. and Smith, J.L. (1977), Chemical and microbiological changes during sausage fermentation and ripening. In: Enzymes in Food and Beverage Processing. ACS Symp. Ser. 47, 279-294.

Papa, F. and Grazia, L. (1990), Produzione ed utilizzazione di coltore starter fresche nell'industria dei salumi. Industrie Alimentari xxix, 537-540.

Papamanoli, E., Kotzekidou, P., Tzanetakis, N. and Litopoulou-Tzanetaki, E. (2002), Characterisation of Micrococcaceae isolated from dry fermented sausage. Food Microbiol. 19, 441-449.
Papamanoli, E., Tzanetakis, N., Litopoulou-Tzanetaki, E. and Kotzekidou, P. (2003), Characterization of lactic acid bacteria isolated from a Greek dryfermented sausage in respect of their technological and probiotic properties. Meat Science, 65, 859-867.

Pereira, K. S. and Pereira, J.L. (2006), Identificação e verificação do potencial enterotoxigênico de Staphylococus ssp. coagulase negativa isolados a partir de salames brasileiros industrializados e avaliação da qualidade microbiológica do produto. Hig. Alimentar, 19, n.129.

Pinto, M.F., Ponsano, E.H.G., Franco, B.D.G.M., Shimokomaki, M. (1998), Controle de Stahylococcus aureus em charque s (Jerked beef) por culturas iniciadoras. Ciên. Tecnol. Aliment., 18, n.2,200-204.

Pinto, M.F., Ponsano, E.H.G. and Heinemann, R.J.B. (2001). Bactérias envolvidas no processamento de produtos cárneos - Uma revisão. Bol. SBCTA, 35 (1/2), 109-116, jan-dez.

Rebecchi, A., Crivori, S., Sarra, P.G. and Cocconcelli, P.S. (1998), Physiological and molecular techniques for the study of bacterial community development in sausage fermentation. Journal of Applied Microbiology, 84, 1043-1049.

Rodriguez, M., Nunez, F., Cordoba, J.J., Bermudez, M.E. and Asensio, M.A. (1998), Evaluation of proteolytic activity of microorganisms isolated from dry cured ham. Journal of Applied Microbiology, 85, 905-912.

Samelis, J., Aggelis, G. and Metaxopoulos, J. (1993), Lipolytic and microbial changes during the natural fermentation and ripening of Greek dry sausages. Meat Sci. 35, 371-385.

Santos, E.M., González-Fernández, C., Jaime, I. and Rovira, J., (1998), Comparative study of lactic acid bacteria house flora isolated in different varieties of chorizo. International Journal of Food Microbiology 39, 123- 128 .

Sorensen, B. B., Stahnke, L. H. and Zeuthen, P. (1993), Pork fat hydrolysed by Staphylococcus xylosus. Rev. Esp. Cienc. Tecnol. Aliment. 33, 165-178.

Stahnke, L.H. (1994), Aroma Components from Dried Sausages fermented with Staphylococcus xylosus. Meat Science, 38, 39-53.

Stahnke, L.H. et al., (2002), Maturity acceleration of Italian dried sausage by Staphylococcus carnosus Relationship between maturity and flavor compounds. Journal of Food Science, 67, 1914-1921.

Talon, R., Montel, M. C. and Cantonnet, M. (1992). Proc. 38th ICoMST, Clermont-Ferrand, 4, p. 839. 
Talon, R., Walter, D., Chartier, S., Barriere, C. and Montel, M. C. (1999), Effect of nitrate and incubation conditions on the production of catalse and nitrate reductase by staphylococci. International Journal of Food Microbiology, 52, 47-56.

Terra, A.; Fries, L. and Terra, N. (2004), Particularidades na fabricação de salame. São Paulo: Varela.

Varnan, A. and Sutherland, J. (1995), Embutidos Fermentados. In: Carne y productos Cárnicos Tecnología, Química e Microbiologia. Zaragoza: Acríbia 307-345.

Zanardi, E. et al., (1998), Oxidative stability and dietary treatment with vitamin E, oleic acid and copper of fresh and cooked pork chops. Meat Science, 49, 309320 .
Zanardi, E. et al., (2002), Lipid and colour stability of Milano-type sausages:effect of packings conditions. Meat Science, 61, 7-14.

Zuber, A.D. and Horvat, M. (2007), Influence of starter cultures on the free fatty acids during ripening in Tea sausages. Eur Food Res Technol, 224, 511-517.

Received: March 10, 2008; Revised: September 24, 2008; Accepted: December 08, 2009. 